\title{
Exchange Rate Uncertainty and Bilateral Trade Flows: Insights from Uganda
}

\author{
Moses H. Lubinga (Corresponding author) \\ Department of Agribusiness \& Natural Resource Economics \\ Makerere University, P.O. Box 7062, Kampala, Uganda \\ Tel: 256-772-183-998Ｅ-mail: moseslubinga@yahoo.co.uk \\ Barnabas Kiiza \\ Department of Agribusiness \& Natural Resource Economics \\ Makerere University, \\ E-mail: bkiiza@agric.mak.ac.ug \\ abkiiza@yahoo.co.uk
}

Received: January 31, 2013 Accepted: February 17, 2013

doi:10.5296/ber.v3i1.3188 URL: http://dx.doi.org/10.5296/ber.v3i1.3188

\begin{abstract}
This study examines the impact of the real exchange rate volatility on the level and volatility of Uganda's bilateral trade flows with several major trade partners. The study uses secondary data in a two-way bilateral trade flow basis between Uganda and seven of her major trading partners. Panel data methods are used in the analysis. The exchange rate used in the panel analysis is the currency rate between the US dollar and Ugandan Shilling. We use GARCH $(1,1)$ to develop measures of volatility for the real exchange rate and bilateral trade flows. The results show that real exchange rate volatility has a negative and significant effect on the level of Uganda's bilateral trade flows. The results also show that real exchange rate volatility has a positive and significant effect on the volatility of bilateral trade flows. Thus, it can be seen that prudential management of the real exchange rate is very crucial for trade promotion and macroeconomic stability.
\end{abstract}

Keywords: Bilateral trade flows, Trade volatility, Exchange rate volatility, Uganda 


\section{Introduction}

In this study we use the gravity flow model to investigate the effects of real exchange rate uncertainty on bilateral trade flows. It must be said that international trade is a crucial instrument for industrialization and sustainable economic development. Recent studies have shown that it is also important to address trade volumes among trade partners rather than only identify the nature of goods traded across countries. This new approach implies that understanding the major determinants of bilateral trade flows of a given country gives policy makers more flexibility in developing research-based trade policies. A number of studies indicate that empirical trade flow analysis can be appropriately done using the gravity flow model. The gravity flow model is widely used in trade policy analysis as a baseline for estimating the impact of a variety of policy issues, such as currency unions, regional trading groups and various trade distortions (see Anderson, 1979; Bergstrad, 1985; Bougheas, Demetriades, \& Morgenroth, 1999; Deardorff, 1998; Eichengrean \& Irwin, 1998; Liu \& Jiang, 2002; Luca \& Vicarelli, 2004; Li, Liu, \& Li,2002; Lin \& Wang, 2004; Sheng \& Liao, 2004). Empirical literature provides conflicting results about the effects of real exchange rate volatility on trade flows. Although many scholars (Cho, Sheldon, \& McCorriston, 2002; Eichengreen \& Irwin, 1995; Frankel, 1997; Frankel \& Wei, 1993; Kandilov, 2008; Thursby \& Thursby, 1987) show that volatility depresses trade flows probably due to risk aversion and costly adjustment of production factors, De Grauwe (1988) and Klein (1990) note that volatility may as well positively influence trade flows due convexity of the profit function relative to the export prices. We use the gravity flow model to estimate the impact of exchange rate uncertainty on bilateral trade flows and their volatility for a developing country. This area of research has received relatively little attention in Sub-Saharan Africa, especially the effect of exchange rate uncertainty on trade volatility. Thus, we hypothesize that real exchange volatility lowers Uganda's level of bilateral trade flows and increases the bilateral trade volatility.

This paper organized is as follows. Section 2 outlines the literature review on the impact of exchange rate uncertainty on bilateral trade flows and trade volatility. Section 3 discusses the model and diagnostic tests. Section 4 describes data while section 5 deals with the results and discussion. Section 6 outlines the conclusion and policy implications.

\section{Brief Review of Literature}

\subsection{Real Exchange Rate Volatility and Bilateral Trade Flows}

Literature shows mixed results about the effects of exchange-rate volatility on trade flows although most of the studies show a negative effect. Those that show little if any effect, include these below. Tenreyro (2004) analyzes exports of 104 countries for the period 1970-1997 using the gravity model with volatility measured as the standard deviation using the moving average approach on the nominal exchange rate. He shows that exchange rate volatility has no effect on trade flows. Similar results are reported by Aristotelous (2001) who uses annual British exports to United States for the period 1889-1999. Hondroyiannis, Patrick, George, and Michael (2008) use a sample of 12 industrialized countries for the period 1977-2003 and find that there is no significant negative impact of volatility on aggregate trade volumes. Klein (1990) observes a 
positive effect.

De Grauwe (1988) notes that risk aversion and costly adjustment of production factors may lead to a negative impact of exchange rate volatility on exports, while convexity of the profit function with respect to export prices may lead to a positive impact. Many studies show a negative effect of exchange rate uncertainty and trade flows. Simwaka (2006) analyses Malawi's trade flows for the period 2000-2004 with seven trading partners using the gravity flow model. He finds a negative effect of exchange rate volatility on bilateral trade flows. Arize, Osang, and Slotjie (2000) and Sauer and Bohara (2001) also report that there exists a negative relationship between the exchange rate volatility and trade flows. Similarly, Dog anlar (2002) approximates volatility using the standard deviation of the real exchange rate and finds that volatility has a negative impact on exports of Turkey, Malaysia, Indonesia South Korea and Pakistan. Poon, Choong, and Habibullah (2005) obtain conflicting results for Indonesia, Japan, South Korea, Singapore and Thailand. They show that although volatility negatively impacts on the exports for Japan, South Korea, and Singapore, it had a significant positive effect on Thailand's trade flows. Grier and Smallwood (2007) use a group of developed and developing countries and find that exchange rate uncertainty plays a significant role in developing countries' exports. Their results concur with those that show a negative effect of exchange rate uncertainty on trade flows. Many more studies have found exchange rate volatility to negatively influence trade flows (see Cho et al. 2002; Eichengreen \& Irwin, 1995; Frankel, 1997; Frankel \& Wei, 1993; Kandilov, 2008; Thursby \& Thursby, 1987). Kandilov (2008) shows that the negative effect of exchange rate volatility on agricultural export trade is more pronounced among the developing economies. Our study differs from others in that we examine the effect of the real exchange rate volatility on both bilateral trade flows and trade volatility.

\subsection{Real Exchange Rate Volatility and Volatility of Bilateral Trade Flows}

Zimmermann (1999) and Engel and Wang (2011) indicate that export and import volatility is in many cases larger than that of GDP. Therefore, it is apparent that trade flow volatility has the potential to seriously affect any given economy at the macro level. Following Baum and Caglayan (2008), we hypothesize that trade flow volatility is positively affected by real exchange rate volatility. This implies that real exchange rate uncertainty plays a large role in trade and the rest of the economy. There are very few studies that have shown interest in examining the relationship between exchange rate uncertainty and trade flow volatility. For a developing country such as Uganda this study opens up a number of questions that include whether the real exchange rate uncertainty has an effect on macroeconomic stability of the economy.

\section{The Model}

\subsection{Trade Flows and Exchange Rate Volatility}

The gravity flow model can be used to predict bilateral trade flows between different geographical entities based on the economic sizes of the different countries, specifically using GDP and the augmented gravity flow model can be written as shown below (see Bergstrand, 
1985; 1989; Chen, Yang, \& Lui, 2007; Deardorff, 1998; Eichengrean \& Irwin, 1998; Foldvari, 2006; Keith, 2003; Luca \& Vicarelli, 2004). We estimate the panel data model as shown below.

$$
\operatorname{lnbtrade}_{i t}=\boldsymbol{\beta X}+\mathbf{e}_{i t} \quad(\mathrm{i}=1, . ., 7 ; \mathrm{t}=1970-2006)
$$

where lnbtrade is the natural logarithm of two-way bilateral trade flows of exports between Uganda and her seven major trading partners. $\boldsymbol{\beta}$ is a vector of parameter estimates, $\mathbf{X}$ is a vector of explanatory variables that include:- log of Uganda's GDP; $\log$ of GDP of trade partner i; log of distance between the Ugandan capital city of Kampala and the capital city of trade partner i; $\log$ of Uganda's population; log of the population of trade partner i; exchange rate volatility; DCOMESA and DEAC which are dummy variables that represent the influence of membership in regional trade blocs, that is, Common Market for East and Southern Africa (COMESA) and East African Community (EAC); DUK which is a dummy that represents having colonial ties to the United Kingdom; and $\mathbf{e}_{\mathrm{it}}$ is a vector of error terms.

\subsection{Trade Flow Volatility and Exchange Rate Volatility}

We estimate the effect of real exchange rate volatility on bilateral trade flow volatility using the following model.

$$
\text { Volbtrade }_{i t}=\beta_{0}+\beta_{1} \text { VolExch }_{\text {it }}+\beta \text { Trend }+\mathrm{e}_{\mathrm{it}}
$$

Where Volbtrade is the bilateral trade volatility; VolExch is the real exchange rate volatility and Trend is a unit step time trend variable. $e_{i t}$ is defined as above. Volbtrade and VolExch are estimated using the simple GARCH(1,1) model (see Andersen \& Bollerslev, 1998; Bollerslev, 1986; Bollerslev, Chou \& Kroner, 1992; Azim, Clark, Tamirisa, \& Wei, 2004; Engle \& Ng, 1993; Sauer \& Bohara, 2001). It allows for volatility clustering such that large variances in the past generate large variances in the future. Hence, volatility can be predicted on the basis of past values. Thus, we have

$$
\begin{gathered}
\Delta \ln X_{\mathrm{t}}=\Omega+\varepsilon_{\mathrm{t}} \\
\varepsilon_{\mathrm{t}} \sim \mathrm{N}\left(0, \mathrm{~h}_{\mathrm{t}}\right) \\
\mathrm{h}_{\mathrm{t}}=\beta_{0}+\beta_{1} \varepsilon_{\mathrm{t}-1}+\beta_{3} \mathrm{~h}_{\mathrm{t}-1}
\end{gathered}
$$

Where $\ln \mathrm{X}_{\mathrm{t}}$ is the $\log$ of the real exchange rate and also the log of bilateral trade flows. Equation (5) gives the conditional variance for the real exchange rate or the bilateral trade flows. In this study the real exchange rate is derived from the purchasing power parity ratio approach. We use the wholesale price index of the United States and the consumer price index of Uganda to derive the real exchange rate.

\subsection{Panel Unit Root Tests}

We use a panel unit root test proposed by Levin, Lin, and Chu, (2002), denoted as LLC, which allows for heterogeneity of the intercepts across members of the panel. We also use the test proposed by Im, Pesaran, and Shin (2003), denoted as IPS, which allows for heterogeneity in the intercepts and the slope coefficients. Both tests are constructed by averaging individual augmented Dickey-Fuller (ADF) t-statistics across cross-section units (Dickey \& Fuller, 1979). The LLC test is for the null hypothesis that each individual time series in the panel is integrated, 
where the alternative hypothesis is that all individual time series are stationary. The test is based on the pooled ADF equation

$$
\Delta y_{i t}=X_{i t}^{\prime} \alpha+\delta y_{i t-1}+\sum_{L=1}^{p_{i}} \beta_{i j} \Delta y_{i t-L}+\varepsilon_{i t}
$$

where a common $\delta=\rho-1$ is assumed, $X_{i t}$ represents the exogenous variables in the models, including any fixed effects or individual trends, and $\rho_{\mathrm{i}}$ is the required country specific degree of lag augmentation to make the residuals white noise that is determined by the conventional step-down procedure. The null hypothesis is $\delta=0$ under the assumption that $\delta_{i}=\delta$ for all $i$ is tested against the alternative hypothesis that $\delta<\delta_{i}$ for all $i$. The test is based on a technique that removes autocorrelation as well as deterministic components. The panel specification for the IPS test is

$$
\Delta y_{i t}=X_{i t}^{\prime} \alpha+\delta y_{i t-1}+\sum_{L=1}^{p_{i}} \beta_{i j} \Delta y_{i t-L}+\varepsilon_{i t}
$$

Where all variables are defined as in (1). However, in this case $X_{i t}$ also includes time dummy variables to account for cross-sectional correlation that could result from common shocks affecting all countries in the panel. The null hypothesis is $\delta=0$ for all $i$ (i.e., all series have a unit root) and is tested against the alternative that $\delta_{i}<0$ for $i=1,2, \ldots, N_{l}$ and $\delta_{i}=0$, for $i=N_{l}$ $+1, N_{2}+2 \ldots N$. On the assumption that the $N$ cross-section units are independently distributed, the t-statistic can be computed as an average of the individual ADF t-statistics,

$$
{ }_{t_{N T}}^{-}\left(p_{i}\right)=\frac{\sum_{i=1}^{N} t_{i T i}\left(p_{i}\right)}{N},
$$

Where $\mathrm{t}_{\mathrm{iTi}}\left(\mathrm{p}_{\mathrm{i}}\right)$ is the t-statistic for testing that $\delta_{i}=0$ in each individual ADF regression. In a further step, the t-bar statistic is standardized so that it converges to a standard normal distribution as $N$ increases. A key strength of the IPS test is that $\delta_{i}$ is allowed to differ across countries and only a fraction of panel members is required to be stationary under the alternative hypothesis.

\subsection{Panel Co-integration Tests}

The second step is to analyze the panel data properties for existence of co-integration among the series. The available techniques for panel co-integration tests are in essence an application of the Engel and Granger (1987) co-integration analysis. As in the analysis of single time series, these approaches test the estimated residuals for stationarity. We use the panel data methods of Kao (1999) and Kao (1999) and Pedroni (2001, 2004) which provide different statistics for this purpose, yet both assume homogenous slope coefficients across countries. To minimize the space devoted to the technical aspects of the different panel co-integration methodologies, we show only the Kao methodology. Although we do not discuss other methodologies, we use the results from the Pedroni residual panel co-integration and the Johansen-Fisher panel co-integration tests to check for consistency of the results. Kao tests the residuals $\hat{e}_{i t}$ of the OLS 


\section{Mll Macrothink}

Business and Economic Research

ISSN 2162-4860

2013, Vol. 3, No. 1

panel estimation by applying DF- and ADF-type tests where the residuals are written as in (9) and (10), respectively.

$$
\hat{\mathrm{e}}_{\mathrm{it}}=\hat{\mathrm{e}}_{\mathrm{it}} \rho_{i t-1}+v_{i t}
$$

and

$$
\hat{\mathrm{e}}_{\mathrm{it}}=\hat{\mathrm{e}}_{\mathrm{it}} \rho_{i t-1}+\sum_{j=1}^{p} \phi_{j} \Delta \hat{\mathrm{e}}_{\mathrm{it}-\mathrm{j}}+v_{i t}
$$

The hypothesis of no co-integration, $\rho=1$, is tested against the alternative hypothesis that the residuals are stationary, $\rho<1$. The OLS estimate of $\rho$ can be written as in (11),

$$
\hat{\rho}=\frac{\sum_{i=1}^{N} \sum_{t=2}^{\mathrm{T}} \hat{e_{i t}} \hat{e_{i t-1}}}{\sum_{i=1}^{N} \sum_{t=2}^{T} \hat{e_{i t}^{2}}}
$$

\section{The Data}

The study focuses on Uganda's seven main trade partners (Switzerland, Belgium, Netherlands, Kenya, South Africa, United Kingdom and France). They were selected basing on the fact that they have been consistent trading partners over the past ten years and have high percentage contribution to total bilateral trade flows with Uganda in recent years. Two market integration blocs are considered, that is, membership to the Common Market for Eastern and Southern Africa (COMESA) and the East African Community (EAC). Kenya and South Africa are members of COMESA, and Kenya also belongs to the EAC. Dummy variables are used to capture the influence of these trading blocs. Another dummy variable is used for colonial ties with the United Kingdom. Distance data are the air distances between the capital cities (Economic centres) of selected trade partners with reference from Kampala, Uganda. These data were taken from www.mapcrow.info/distance and www.worldatlas.com. This study concentrates on panel data collected over the period 1970 - 2006. The use of panel data has several advantages over cross sectional analysis. According to Martinez-Zarzoso and Nowak-Lehmann (2003), it is possible to capture the relevant variable relationships over time and panels enhance monitoring the possible unobserved trading-pair individual effects. Data were obtained from the International Financial Statistics (IFS) database of the IMF; the Uganda Bureau of Statistics; the United Nations Statistics Division Common Database. All relevant data are in 1990 constant prices.

\section{Results}

\subsection{Diagnostic Tests}

The diagnostic test results are shown in Tables 1 and 2 below. The unit root tests following the LLC and IPS methods indicate that the variables in the model are integrated of first order as shown in Table 1 below. In Table 2, we test for co-integration between bilateral trade flows and real exchange rate volatility using the Pedroni method. We find that the two variables are 


\section{Al Macrothink}

Business and Economic Research

ISSN 2162-4860

2013, Vol. 3, No. 1

indeed co-integrated. Similar results are obtained for cointegration between trade flow volatility and exchange rate volatility. The null hypothesis of no co-integration is rejected in both cases.

Table 1. Panel Unit Root Test Results

\begin{tabular}{|l|l|l|l|l|}
\hline Variable & \multicolumn{2}{|l|}{ LLC Method (t-statistic) } & \multicolumn{2}{l|}{ IPS Method (Wald-statistic) } \\
\hline & Levels & First Difference & Levels & First Difference \\
\hline Lnbtrade & -0.956 & $15.227 * * *$ & -0.826 & $-15.486 * * *$ \\
\hline lnExt_gdp & -0.121 & $-8.695 * * *$ & -0.749 & $-7.399 * * *$ \\
\hline lnUg_pop & 1.033 & $-14.958 * * *$ & 0.563 & $-12.674 * * *$ \\
\hline lnExt_pop & 0.065 & $-11.780 * * *$ & -0.17159 & $-11.408 * * *$ \\
\hline lnUg_gdp & - & - & 0.63932 & $-5.445 * * *$ \\
\hline VolExch & 0.505 & $-39.489 * * *$ & 3.516 & $-36.406 * * *$ \\
\hline Volbtrade & 2.258 & $-14.556 * * *$ & - & - \\
\hline
\end{tabular}

Note: $* * * * *, *$ denote significance at $1 \%, 5 \%$ and $10 \%$ level.

Table 2. Panel Co-integration Test Results

\begin{tabular}{|c|c|c|}
\hline \multicolumn{3}{|c|}{ Pedroni Test (variables: Inbtrade and VolExch) } \\
\hline \multicolumn{3}{|c|}{ Null Hypothesis: No Cointegration } \\
\hline \multicolumn{3}{|c|}{ Alternative hypothesis: common AR coefs. (Within-dimension) } \\
\hline & Statistic & Prob. \\
\hline Panel v-Statistic & 1.553831 & 0.0601 \\
\hline Panel rho-Statistic & -3.950132 & 0.0000 \\
\hline Panel PP-Statistic & -3.204022 & 0.0007 \\
\hline Panel ADF-Statistic & -1.645725 & 0.0499 \\
\hline \multicolumn{3}{|c|}{ Alternative hypothesis: individual AR coefs. (Between-dimension) } \\
\hline & Statistic & Prob. \\
\hline Group rho-Statistic & -2.219141 & 0.0132 \\
\hline Group PP-Statistic & -2.676039 & 0.0037 \\
\hline Group ADF-Statistic & -0.453961 & 0.3249 \\
\hline \multicolumn{3}{|c|}{ Pedroni Test (Variables: Volbtrade and VolExch) } \\
\hline \multicolumn{3}{|c|}{ Null Hypothesis: No cointegration } \\
\hline \multicolumn{3}{|c|}{ Alternative hypothesis: common AR coefs. (Within-dimension) } \\
\hline & Statistic & Prob. \\
\hline Panel v-Statistic & 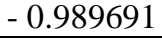 & 0.8388 \\
\hline Panel rho-Statistic & -11.84798 & 0.0000 \\
\hline Panel PP-Statistic & -10.19135 & 0.0000 \\
\hline Panel ADF-Statistic & -10.21970 & 0.0000 \\
\hline \multicolumn{3}{|c|}{ Alternative hypothesis: individual AR coefs. (Between-dimension) } \\
\hline & Statistic & Prob. \\
\hline Group rho-Statistic & -10.53281 & 0.0000 \\
\hline Group PP-Statistic & -11.82326 & 0.0000 \\
\hline Group ADF-Statistic & -11.76924 & 0.0000 \\
\hline
\end{tabular}

After establishing that there exists a long run equilibrium relationship amongst the variables of interest in Table 2 above, we go ahead and examine the effect of exchange rate volatility on both bilateral trade flows and volatility.

\subsection{Exchange Rate Volatility on Bilateral Trade Flows}

We employ a random effects Prais-Winsten AR(1) model with panel corrected standard errors 
and covariance. We determine the effect of the real exchange rate volatility on the bilateral trade flows using the augmented gravity model and the results are presented in Table 3 below.

Table 3. Impact of Exchange Rate Volatility on Bilateral Trade Flows

\begin{tabular}{|c|c|c|}
\hline Dependent Variable $=$ & natural $\log$ of Bilat & ade Flov \\
\hline Variables & \begin{tabular}{l|l} 
& Coefficient \\
\end{tabular} & p-value \\
\hline Constant & 9.121 & 0.013 \\
\hline lnUg_GDP & $1.261 * *$ & 0.045 \\
\hline lnExt_GDP & $0.999 * *$ & 0.014 \\
\hline lnUg_Pop & -0.501 & 0.611 \\
\hline lnExt_Pop & $-0.800 * *$ & 0.040 \\
\hline lnDistance & $-2.036 * * *$ & 0.000 \\
\hline VolExch & $-1.318 * *$ & 0.030 \\
\hline DCOMESA & 0.583 & 0.227 \\
\hline DEAC & -0.526 & 0.243 \\
\hline DUK & $1.765 * * *$ & 0.000 \\
\hline $\mathrm{N}$ & 245 & \\
\hline Wald $\mathrm{Chi}^{2}(10)$ & 116.88 & \\
\hline $\mathrm{p}$-value $\mathrm{Chi}^{2}(10)$ & 0.0000 & \\
\hline R-squared & 0.5031 & \\
\hline
\end{tabular}

Note: $*, * *, * * *$ denote statistical significance at the $1 \%, 5 \%$, and $10 \%$ levels.

With the exception of the dummy variables denoting membership to East African Community (DEAC) and COMESA (DCOMESA) and Uganda's population (lnUg_Pop), all other explanatory variables are found to be statistically significant. Uganda's real GDP (Ug_GDP), trade partners' real GDP (Ext_GDP), population of Uganda's trade partners (lnExt_Pop), distance (lnDist), real exchange rate volatility (VolExch), and having colonial ties with the United Kingdom (DUK) are identified as some of the major factors influencing Uganda's bilateral trade flows with a sample of her trade partners.

Our variable of interest is the exchange rate volatility (VolExch). Following Kandilov (2008), this study considers only the vehicle currency exchange rate, that is, that between the US dollar and the Ugandan shilling and not that between export and importer countries. The results show that real exchange rate volatility has a negative and significant effect on Uganda's bilateral trade flows. It shows that a $1 \%$ increase in the real exchange rate volatility decreases bilateral trade flows by $1.32 \%$.

This result may be attributed to the fact that Uganda's trade, especially exports, are dominated by agricultural commodities which Kandilov (2008) notes to be very sensitive to exchange rate volatility. He indicates that exchange rate volatility has a small negative effect on non-agricultural trade flows yet its impact on agricultural trade flows is about ten times relative to trade in other commodities. Similar results are obtained by Cho et al. (2002); Eichengreen and Irwin (1995); and Frankel and Wei (1993). Primary commodity contribution to total exports for Uganda has been high, ranging between $70.4 \%$ and $48 \%$ since 2001 . For example, during 2002, unprocessed coffee, tea and tobacco alone accounted for $39.1 \%$ of total exports with coffee contributing about $21 \%$ of total exports.

\subsection{Exchange Rate Volatility and Bilateral Trade Volatility}




\section{Ml Macrothink}

Business and Economic Research ISSN 2162-4860 2013, Vol. 3, No. 1

We use dynamic generalized least squares to determine the effect of exchange rate uncertainty on bilateral trade volatility and the results are shown in Table 4 below. Exchange rate volatility has a positive and significant impact on bilateral trade volatility. A $1 \%$ increase in exchange rate volatility increases trade flow volatility by about $0.80 \%$. These findings are consistent with those of Baum and Caglayan (2009) who find the same effect for industrialized and newly industrializing countries.

Table 4. Impact of Exchange Rate Volatility on Bilateral Trade Volatility

\begin{tabular}{|l|l|l|}
\hline Dependent Variable $=$ & \multicolumn{3}{|c|}{ Volatility of Bilateral Trade Flows } \\
\hline Variables & Coefficient & p-value \\
\hline Constant & 0.036 & 0.732 \\
\hline VolExch & $0.771^{* *}$ & 0.018 \\
\hline Time Trend & 0.007 & 0.046 \\
\hline R-squared & 0.141 & \\
\hline Adj. R-squared & 0.101 & \\
\hline F-statistic & 3.495 & \\
\hline Prob(F-statistic) & 0.000 & \\
\hline $\mathrm{N}$ & 224 & \\
\hline
\end{tabular}

Note: $* * *, * * *$ denote statistical significance at the $1 \%, 5 \%$, and $10 \%$ levels.

\section{Conclusions and Implications}

We find that real exchange rate volatility depresses Uganda's bilateral trade flows. This result is consistent with many others in the literature for developing countries. The results also show that real exchange rate volatility increases the volatility of bilateral trade flows. Both effects are significant and thus this has policy implications for the government to ensure prudential management of the exchange rate. It cannot be over-emphasized that the consequences of depressed trade flows which also happen to be volatile has serious economic growth implications for a developing country such as Uganda. Therefore it implies that government has to employ appropriate tools or monetary policies that foster macroeconomic stability. For a developing country such as Uganda, with a market determined exchange rate, it is necessary to ensure that the macroeconomic fundamentals that affect the exchange rate are well managed to mitigate the volatility.

\section{Acknowledgement}

We extend our thanks to the African Economic Research Consortium (AERC) that partially funded this study. We acknowledge the anonymous reviewers whose constructive comments helped improve the manuscript.

\section{References}

Andersen, T., \& Bollerslev, T. (1998). Answering the skeptics: yes standard volatility models do provide accurate forecasts. International Economic Review, 39(4), 885-905. http://dx.doi.org/10.2307/2527343

Anderson, J. E. (1979). A theoretical foundation for the gravity equation. American economic review, 69(1), 106-116. http://www.jstor.org/stable/1802501 
Aristotelous, K. (2001). Exchange-rate volatility, exchange-rate regime, and trade volume:

Evidence from the UK-US export function (1889-1999). http://dx.doi.org/10.1016/S0165-1765(01)00414-1

Arize, A. C., Osang, T., \& Slotjie, D. J. (2000). Exchange-rate volatility and foreign trade: Evidence from thirteen LDCs. Journal of Business and Economic Statistics, 18(1), 10-17. http://www.jstor.org/stable/1392132

Azim, S., Clark, P. B., Tamirisa, N. T., \& Wei, S. (2004). A New Look at Exchange Rate Volatility and Trade Flows. Washington, DC: International Monetary Fund.

Baum, C., \& Caglayan, M. (2009). The volatility of international trade flows and exchange rate uncertainty. Boston College, USA: Manuscript in preparation. Retrieved February 14 2013. http://fmwww.bc.edu/ec-p/wp695.pdf

Bergstrand, J. H. (1989). Trade generalized gravity equation, monopolistic competition, andthe factor-proportions theory in international trade. Review of Economics and Statistics, 71(1), 143-153. http://www.jstor.org/stable/1928061

Bergstrand, J. H. (1985). The gravity equation in international trade: Some microeconomic foundations and empirical evidence. Review of Economics and Statistics, 67(3), 474-481. http://dx.doi.org/10.2307/1925976

Bollerslev, T. (1986). Generalized autoregressive conditional hetroscedasticity. Journal of Econometrics, 31(3), 307-327. http://dx.doi.org/10.1016/0304-4076(86)90063-1

Bollerslev, T. R., Chou, Y., \& Kroner, K. F. (1992). ARCH modeling in finance. Journal of Econometrics, 52(2), 5-59. http://dx.doi.org/10.1016/0304-4076(92)90064-X

Bougheas, S., Demetriades, P. O., \& Morgenroth, E. L. W. (1999). Infrastructure, transport costs and rade. Journal of International Economics, 47(1), 169-189. http://dx.doi.org/10.1016/S0022-1996(98)00008-7

Chen, X., Yang, Z., \& Lui, X. (2008). Empirical analysis of Xinjiang's bilateral trade: Gravity model approach. Chinese Geographical Science, 18(1), 9-16. http://dx.doi.org/10.1007/s11769-008-0009-5

Cho, G., Sheldon, I., \& McCorriston, S. (2002). Exchange rate uncertainty and agricultural trade. American Journal of Agricultural Economics. 84(4), 934-942. http://dx.doi.org/10.1111/1467-8276.00044

Deardorff, A. V., (1998). Determinants of bilateral trade: Does gravity work in a neoclassical world? In J. A. Frankel, The Regionalization of the World Economy (ed., pp. 7-32).Chicago: University of Chicago Press.

De Grauwe, P. (1988). Exchange rate volatility and the slowdown in growth of international trade. IMF Staff Papers, 35(1), 63-84. http://dx.doi.org/10.2307/3867277

Dickey, D. A., \& Fuller, A. W. (1979). Distribution of the estimators for autoregressive time 
series with a unit root. Journal of the American Statistical Association, 74(366), 427-431. http://dx.doi.org/10.2307/2286348

Dog anlar, M. (2002). Estimating the impact of exchange rate volatility on exports: Evidence from Asian countries. Applied Economics Letters, 9(13), 859-863. http://dx.doi.org/10.1080/13504850210150906

Eichengreen, B., \& Irwin, D. (1995). Trade blocs, currency blocs and the reorientation of trade in the 1930s. Journal of International Economics, 38(1), 1-24. http://dx.doi.org/10.1016/0022-1996(95)92754-P

Eichengrean, B., \& Irwin, D. (Eds.) (1998). The role of history in bilateral trade flows. In J. A. Frankel. The Regionalisation of the World Economy (ed.). Chicago: University of Chicago Press.

Engel , C., \& Wang, J., (2011). International trade in durable goods: Understanding volatility, cyclicality, and elasticities. Journal of International Economics, 83(1), 37-52. http://dx.doi.org/10.1016/j.jinteco.2010.08.007

Engle, R., \& Granger, C. W. J. (1987). Cointegration and error correction: Representation, estimation and testing. Econometrica, 55(2), 251-276. http://dx.doi.org/10.2307/1913236

Engle, R. F., \& Ng, V. (1993). Measuring and testing the impact of news on volatility. Journal of Finance, 48(5), 1749-1778. http://dx.doi.org/10.1111/j.1540-6261.1993.tb05127.x

Foldvari, P. (2006). The economic impact of the European integration on Netherlands. A quantitative analysis of foreign trade and foreign direct investments. Utrecht University, http://www.temoa.info/node/348257

Frankel, J., \& Wei, S. (1993). Trade blocs and currency blocs. National Bureau of Economic Research (NBER): (Working Paper Series No. 4335). Cambridge: NBER, pp.52.

Frankel, J. (1997). Regional Trading Blocs in the World Trading System. Washington, DC: Institute for International Economics, xv, 364.

Grier, K. B., \& Smallwood, A. D. (2007). Uncertainty and export performance: Evidence from 18 Countries. Journal of Money, Credit and Banking, 39(4), 965-979. http://dx.doi.org/10.1111/j.1538-4616.2007.00053.x

Hondroyiannis, G., Patrick, S., George, T., \& Michael, U. (2008). Some further evidence on exchange-rate volatility and exports. Review of World Economics, 144(1), 151-280. http://dx.doi.org/10.1007/s10290-008-0141-4

Im, K., Pesaran, M. H., \& Shin, Y. (2003). Testing for unit root in heterogeneous panels. Journal of Econometrics, 115(1), 53-74. http://dx.doi.org/10.1016/S0304-4076(03)00092-7

Kandilov, I. T. (2008). The effects of exchange rate volatility on agricultural trade. American Journal of Agricultural Economics, 90(4), 1028-1043. http://dx.doi.org/10.1111/j.1467-8276.2008.01167.x 
Kao, C. (1999). Spurious regression and residual-based tests for cointegration in panel data. Journal of Econometrics, 90 (1), 1-44. http://dx.doi.org/10.1016/S0304-4076(98)00023-2

Keith, H. (2003). Gravity for beginners. University of British Columbia, Faculty of Commerce. www.economics.ca/keith/gravity.pdf

Klein, M. (1990). Sectoral effects of exchange rate volatility on United States exports. Journal of International Money and Finance, 9(3), 299-308. http://dx.doi.org/10.1016/0261-5606(90)90011-N

Levin, A., Lin, C., \& Chu, C. (2002). Unit root tests in panel data: Asymptotic and finite-sample properties. Journal of Econometrics, 108(1), 1-24. http://dx.doi.org/10.1016/S0304-4076(01)00098-7

Li, L., Liu, Z., \& Li, C. (2002). Spatial correlation analysis of crop yield in the middle and West of Jilin Province. Chinese Geographical Science, 12(2), 182-185.http://dx.doi.org/10.1007/s11769-002-0029-5

Lin, L., \& Wang Y. (2004). Empirical test of China's bilateral trade with the trade gravity model and its policy implications. World Economy Study, 7, 56-60.

Liu, Q., \& Jiang, S. (2002). Study on the Chinese bilateral trade arrangement using the gravity model. Zhejiang Social Sciences, 6, 17-20.

Luca, D. B., \& Vicarelli, C. (2004). Trade Potentials in Gravity Panel Data Models. Topics in Economic Analysis \& Policy, 5(1), Article 20. http://dx.doi.org/10.2139/ssrn.506562

Martinez-Zarzoso, I., \& Nowak-Lehmann, F. (2003). Augmented gravity model: An empirical application Mercosur-European Union trade flows. Journal of Applied Economics, 6(2), 291-316. http://ssrn.com/abstract=583982

Pedroni, P. (2001). Purchasing power parity tests in cointegrated panels. Review of Economics and Statistics, 83 (4), 727-731. http://dx.doi.org/10.1162/003465301753237803

Pedroni, P. (2004). Panel cointegration: Asymptotic and finite sample properties of pooled time series tests, with an application to the PPP hypothesis. Econometric Theory, 20, 597-625. http://dx.doi.org/10.1017/S0266466604203073

Poon, W. C., Choong, C. K., \& Habibullah, M. S. (2005). Exchange rate volatility and exports for selected East Asian countries: Evidence from error correction model. ASEAN Economic Bulletin, 22(2), 144-159. http://dx.doi.org/10.1355/AE22-2B

Sauer, C., \& Bohara, A. K. (2001). Exchange rate volatility and exports: Regional differences between developing and industrialized countries. Review of International Economics, 9(1), 133-52. http://dx.doi.org/10.1111/1467-9396.00269

Sheng, B., \& Liao, M. (2004). China's trade flows and export potential: The gravity model approach. World Economy, 27(2), 4-10.

Simwaka, K. (2006). Dynamics of Malawi's trade flows: A gravity model approach.Munich 


\section{Macrothink}

Business and Economic Research ISSN 2162-4860

Personal RePEc Archive (MPRA): (MPRA Paper No. 1122). Munich: MPRA: Research and Statistics Department, pp. 13. http://mpra.ub.uni-muenchen.de/1122/.

Tenreyro, S. (2004). On the trade impact of real exchange rate volatility. Federal Reserve Bank (FRB): (Working Paper Series No. 03-2). Boston. pp. 39. http://dx.doi.org/10.2139/ssrn.648225

Thursby, J., \& Thursby, M. (1987). Bilateral trade flows, the Linder hypothesis and exchange rate risk. Review of Economics and Statistics, 69(3), 488-495. http://dx.doi.org/10.2307/1925537

Zimmermann, C. (1999). International business cycles and exchange rates. Review of International Economics, 7(4), 682-698. http://dx.doi.org/10.1111/1467-9396.00193

\section{Copyright Disclaimer}

Copyright reserved by the author(s).

This article is an open-access article distributed under the terms and conditions of the Creative Commons Attribution license (http://creativecommons.org/licenses/by/3.0/). 